\title{
The Effects of using Digitally Supported Concept Maps Method in Science Classes in Primary Education on the Academic Success and Students' Opinions
}

\author{
Mutlu Uygur* \\ Department of Curriculum and Instruction, Faculty of Education, Mersin University, Mersin, Turkey \\ *Corresponding Author: mutluygur@gmail.com
}

\section{ABSTRACT}

In this research, the effects of using digitally supported concept maps on the academic success of students in science classes in primary education and their opinions toward the advantages of digitally supported concept maps were examined. The research was conducted with seventh-grade students in a state school in Turkey. This research used a quasi-experimental design with two groups employing a pre-test/ post-test. A total of 44 students participating in this study: Twenty-two students in the experiment group and 22 students in the control group. The control group of students experienced the concept maps using pencil and paper (manual) while the experiment used digital education materials. The data were analyzed through t-test to determine whether there was a significant difference between academic success points and then analyzed through content analysis. According to the results of the research, the students who experienced the digitally supported concept maps increased their academic success. These students reported that "learning takes place more easily" through this method. The results of this research show that the students got entertained and motivated much more in the environments that digitally supported concept maps were used.

KEY WORDS: concept map; digitally supported concept map; primary education students; science education; technology

\section{INTRODUCTION}

M any teachers would argue that their students need not only to give their attention but also apply their concentration on the topic for learning to occur. Hence, looking for ways that stimulate students in learning and then teachers using this in their teaching is one of the most important indicators in the art of teaching (Erden and Fidan, 1998). There are several educational tools that help cognitive activities in the learning process. These tools are called teaching materials. At present, teaching materials containing digital technologies are used besides non-digital teaching materials as teaching materials in education environments (Bullock, 2013; Hoyles et al., 2004; Palaiologou, 2016).

In the rapidly changing and developing world, it is no longer expected for students to get all their information from just one source and memorize it. On the contrary, in Turkey, the aim of education is both to raise its citizens knowing how to access and use information as well as having the capacity to use this information to develop their own solutions when encountering a problem. The usage of teaching materials that are appropriately prepared according to the principles of teaching technologies has an important place in developing these characteristics in people. As such, teachers need to establish an efficient and interactive learning environment (Şahin and Yıldırım, 1999). Their teaching materials are then used to support teaching. Good materials enrich the education process, make the learning easier by embodying the information and motivating the student, help the acquisition of knowledge, help engage the student's attention, encourage their willingness to learn, contribute to the conceptualization of thinking, and make the learning environment natural (Aslan and Doğdu, 1993; Özyürek, 1998). According to Ergin (1995), methods appealing to different kind of senses, such as seeing, hearing, and feeling must be used to support students' learning. In teaching, the more you appeal to the sensory organs, the greater the efficiency of teaching and learning becomes more significant, permanent, and rapid.

\section{LITERATURE REVIEW}

Visual teaching materials have been reported to be efficient tools in the teaching-learning process (Abebe and Davidson, 2012; Bergeron et al., 1994; Yaşar and Şeremet, 2010). Visual teaching materials are often the illustrations of our oral knowledge, such as movies, computer and television screenshots, slides, photographs, and concept maps (Akgün, 2000). Visual teaching materials become assistants and guides for students in gathering attention, analyzing, and synthesizing information. A welldesigned schematic representation provides a complete and comprehensive visual that words alone cannot convey and often make the recall of the information easier.

Design is the first thing to emphasize while developing teaching materials. Design is defined as the conscious effort for a meaningful order (Kılıç, 1997). At the present time, it has been 
accepted that teaching takes place conceptually not functionally. This view makes concept of teaching more important in the teaching process. In more traditional teaching methods, a word defining the concept was stated, the definition was presented, definitive and discriminant qualities were expressed regarding the concept and teachers wanted the student to find examples that were part or not part of the concept (Akgün, 2000).

At present, it is fundamental for the student to construct the information in modern education methods. The information gets constructed more easily when the concepts are embodied. Semantic feature analysis tables, concept networks, and concept maps are used to present the concepts visually. Concept maps (Novak and Gowin, 1984) based on meaningful learning theory (Ausubel, 1963) are teaching and learning methods supporting people acquiring and interpreting information. According to the model of meaningful learning, learning occurs when students integrate the new learning with their prior knowledge and a meaningful connection occurs between these sets of information. This differs from rote learning where the student acquires the information without making any connection with their previous information (for example, Atasoy, 2004. p. 171-199).

In science education, many concepts and their related facts are abstract and therefore, visually presented so that students are able to access this information. Therefore, using the right method is very essential to support students' meaningful learning. Science classes naturally depend on observation and experiment. On account of this, effective learning in science classes often requires student observations and active participation in the experiments. In addition, science classes like other subject classes seek to develop students' critical thinking whereby student learn to apply their thinking to problem-solving (Turgut et al., 1997). As such, concept maps actively support the student by helping the student organize the information. Concept maps are frequently used not only as a teaching method but also an assessment tool in activities and studies. When literature was examined related to the area of using concept maps, concept maps were generally seen to be used as effective teaching method (Çakmak, 2018; Okursoy, 2009; Y1lmaz and Çolak, 2012) and as a tool in an assessment of a lesson, implementation or an activity (Baki and Şahin, 2004; Daley et al., 1999; Kaya, 2003; Ören and Ateş, 2018; Şahin, 2002).

Concept maps are teaching-learning methods that show how people acquire and make the information meaningful, support the student's mental organization of the information, help the researching of conceptual interchange or two-dimensional tools that can be used in any part of teaching (Karamustafaoğlu et al., 2005; Şahin, 2002).

Concept maps are two-dimensional schemas that show the correlation of concepts among themselves in aspect and direction. Computer-based concept maps are generated by designing concept maps in digital setting by means of computers (mobile or non-mobile devices) and using in educational environment (Alpert and Grueneberg, 2000; Bruillard and Baron, 2000; Chang et al., 2001; Fisher, 1990; Kwon and Cifuentes, 2009; Mutlu, 2009; Tzeng, 2009).
In literature, instead of "computer-aided concept maps," the statement "digitally supported concept maps" or "digital concept maps" is often used as a more comprehensive expression in which digital technologies are used efficiently and shared online (Engelmann and Hesse, 2010; Tergan, 2005; Tergan et al., 2006). Therefore, in this research, the expression "digitally supported concept maps" is used. Digitally supported concept maps are the concept maps that are used in web-based learning environments (Aydoğdu, 2016). According to Tergan et al. (2006), digitally supported concept maps are a method that can be used in education and workplace environments as bridging technology for the purpose of integrating the opinion of visualizing information, overcoming the deficiencies of existing approaches, and developing the management of the information.

\section{PROBLEM OF RESEARCH}

As noted, digitally supported concept maps are helpful and useful teaching methods for teachers. The basic fundamentals in teaching are for the provided information to be retained in the students' minds for a long time, easy to understand, and for the students to connect the new information with both prior knowledge and other introduced concepts. Concept maps and digitally supported concept maps are two of the effective ways to reach these aims. According to Şahin (2001), meaningful learning occurring by means of this method takes place in longterm memory by the making of the strong hierarchical structures required for comprehensive concepts. There are different advantages to preparing and implementing concept maps. Tergan et al. (2006) stated that digital concept maps constructed by advanced computer-based concept mapping tools have both the possibilities of forming visual representation of propositions representing the idea and concept knowledge and also the possibilities of presenting the multimedia exhibitions of separate events, visions, animations, and simulations. When the research literature was examined, concept maps were mostly prepared manually without the support of a computer and students had no possibility of improving this concept maps by means of online sharing (Chiou, 2008; Daley et al., 1999; Hsu, 2004; Karpicke and Blunt, 2011). According to Prensky (2004), developing technology is becoming the center of the lives of modern-day students referring to them as the "digital generation." Online activities are an inseparable part of the daily lives of the digital generation. One-to-one interaction of digital generation with technology greatly affects the characteristics of learning. The digital generation gets motivated more easily in the lesson when the methods containing technology are used in their learning environment. In this regard, this study decided to use concept map supported with digital applications and providing online sharings to focus the attention and interest of modern-day students.

\section{Research Focus}

In this direction, the aim of the research was to detect whether there was a significant difference in the academic success of students. One group was taught using traditional methods, the control group, and the other taught using the application 
of digitally supported concept maps, the experimental group. Both groups were taught an "electricity unit" taking place in the "physical phenomenon" learning area in a seventh-grade science class in Mersin, Turkey. The study sought to determine the opinions of the experimental group students toward the benefits of the digitally supported concept maps. In this direction, the questions below were investigated:

a) Is there a significant difference between the pre-test success grades of the experimental and control group?

b) Is there a significant difference between pre-test/post-test success grades of the control group?

c) Is there a significant difference between pre-test/post-test success grades of the experimental group?

d) Is there a significant difference between post-test success grades of the experimental and control group?

e) What are the opinions of students' int the experimental group towards the benefits of digitally supported concept maps?

\section{METHODOLOGY}

\section{General Background of Research}

A quasi-experimental design was used in this research. There were both an experiment and control groups in this study's quasi-experimental design. In this research, both groups were administered a pre-test and post-test; however, the digitally supported concept maps were only offered to the experimental group (Creswell, 2003; Karasar, 2005). The researcher used quasi-experimental design with pre-test/post-test in both the experimental and control groups, the academic success of the students was assessed with dependent variable both in the beginning and end of the research.

This research study randomly selected two seventh grade classes, one as the experimental group and one as the control group. This was done to determine what, if any, were the effects of digitally supported concept maps on students' academic success. These concept maps were incorporated in an electricity unit taking place in the physical phenomenon learning area of seventh-grade science classes. While the experimental group experienced activities which included digitally supported concept maps performed in both teamwork and online student arrangements, while the control group experienced their usual lesson content using a traditional teaching method.

\section{Research Participants}

For this research study, there were 44 students who participated. These students were in the seventh grade in a state school in Mersin, Turkey, in 2017. The school, where the research was conducted, is a school locating in the Southeastern Anatolia Region and a district containing a large number of immigrants from Syria. The students were randomly divided into two, 22 in the experimental group and 22 in the control group. The pre-test results and the previous academic year-end science class average indicated that both the experimental and control groups were at the same academic level at the start of the study. Demographics of the participants are given in Table 1.

\section{Instrument and Procedures}

Academic success test

"Science class academic success test" is a survey instrument comprised of 20 items using five multiple choice answers. It was designed by the researcher to assess the cognitive introduction behaviors of both groups. The test's validity and reliability were applied to both the experimental and control group as pre-test and post-test.

\section{Open-ended opinion form}

An opinion form containing one open-ended question was designed and offered to students to capture the opinions of the students about the benefits of digitally supported concept maps.

\section{Data Analysis}

t-test was implemented to analyze the data acquired using SPSS analysis program. The upper limit of the error margin was accepted as 0.05 to test the significance of the data acquired. Skewness and kurtosis values were examined to test the normality acquired from control and experiment group. A skewness value between -1.96 and +1.96 is accepted as an indicator of normal distribution in a sample of $<50$ participants. When the coefficient of skewness is divided by its standard error, and the coefficient of kurtosis is divided by its standard, distribution can be accepted as normal if the values are between -1.96 and +1.96 (Can, 2017). In this research, the coefficient of skewness and coefficient of kurtosis were found to be within the \pm 1.96 gap. According to these values, the data were determined to have a normal distribution for all tests $(\rho>0.05)$.

According to data, as assumptions of the parametric test were met, t-test was used for non-paired samples and paired samples out of parametric tests in the analysis of data. In the analysis of qualitative data, content analysis was applied to the data. The data that were analyzed were classified according to code and categories.

\section{Validity and Reliability \\ Experimental pattern}

Validity and reliability are important factors in experimental research. The reliability of the assessment tool is an important factor supporting the reliability of the experiment. The findings related to academic success test show that this research's assessment tool is reliable $(\alpha=0.86)$. Another important factor

\begin{tabular}{lcc}
\hline \multicolumn{3}{l}{ Table 1: Demographic information about participants } \\
\hline Variables & \multicolumn{1}{c}{ Experimental group } & Control group \\
\hline Age & 6 & 5 \\
$\quad 12$ years old & 16 & 17 \\
13 years old & & \\
Gender & 11 & 10 \\
$\quad$ Male & 11 & 12 \\
Female & 6.84 & 6.78 \\
Previous year academic & & \\
year-end results & 8.41 & 8.14 \\
Pre-test results &
\end{tabular}


that must be found in experimental research is internal validity. There are reasons that might affect the internal validity negatively, such as the loss of a test participant, the setting in which the data were collected, and the loss of quality of data collection tool. In this study, participants were not lost over the length of the research. The equivalence of groups where the data were collected was administered paying attention to the proximity of last year's academic success grade averages in science classes. In addition, the equivalence of the classes in terms of socioeconomic aspect was also taken into consideration. Another factor threatening the internal validity is whether the data collection tools assess the thing that is wished to be assessed. Opinions of experts were conducted on all assessment tools so as to provide internal validity. The academic success test was verified by one academic and three science teachers. As a result of their expert views, the test was decreased from its original 30 questions to 25 .

The content validity of the test was examined through the table of specifications, and the test was administered to 39 students from a seventh-grade class as a pilot to assess the construct validity. As a result of pre-trial, KR-21 reliability coefficient of academic success test was found $(\alpha>0.70) 0.86$ in the reliable gap (Büyüköztürk, 2011). As a result of item analysis, it was decided to remove five more questions from the successful test and make the final assessment tool 20 questions.

The differences between applicators are another factor impacting on internal validity in experimental studies. In this research, the lessons in both the experimental and control group were practiced under the control and guidance of the researcher as a means to mitigate these factors.

\section{Qualitative design}

Topkaya (2006) states that the truth of results, namely, validity is more important than the repeatability of the results, namely, reliability in qualitative research. Two academic opinions were consulted to provide the content validity and face validity of this study's qualitative assessment tool. The question has been offered as an open-ended opinion form after the experts' views. The opinions of four students in seventh grade were also taken into consideration. It was decided to incorporate the open-ended question. To be able to make the qualitative research valid, being objective is the first condition (Roberts and Priest, 2006). The findings were divided into coded categories by analyzing the answers to the open-ended question with two coders to decrease the bias. The formula of Miles-Huberman coder reliability has been used for coder reliability of findings acquired from open-ended question (Miles and Huberman, 1994). As a result of the implementation of the coder reliability formula, the coherence between the two coders was found to be 0.87 . This indicated that the coding had been done reliably.

\section{Procedures}

Six learning outcomes direct the "electricity unit" activities in the "physical phenomenon" learning area in seventh-grade science class. These learning outcomes are shown in Table 2.
The students in the experimental group prepared their activities using digitally supported concept maps for a total of $15 \mathrm{~h}$ over 3 weeks. The class was divided into four groups to prepare the concept maps about the learning outcomes. This was done so that every student had an active role in the preparation of the concept maps in accordance with the principles of the collaboration system. After the students designed their concept maps through teamwork, they drew their maps using a free version of concept map application Webspiration Classroom and LucidChart. Social sharing platforms have been used to draw concept maps in the digital environment, to interpret and make corrections to concept maps. Hence, this study intended to improve student activities on digital platforms in an interactive educational environment. The procedures for the experimental group are given in Table 3 .

The students were in the control group similarly divided into four groups. These students were also provided instructions on how to generate concept maps. The only difference between the two groups was the control group students manually drew their concept maps using pencil and paper. These students also presented and interpreted concept maps at the end of the unit in the classroom. The academic success test was administered to the control group as a pre-test and post-test.

\section{FINDINGS}

t-test analysis was applied for non-paired samples so as to examine the difference between the pre-test grades of academic success of the students taking place in both the experimental and control group. In Table 4, the results of t-test analysis are given.

For the non-paired samples in Table 4, a significant difference was not found $(\mathrm{t}(42)=0.767, \rho>0.05)$. As a result of the

\begin{tabular}{|c|c|c|c|}
\hline Number & Learning outcomes & Concepts & Learning area \\
\hline 1 & $\begin{array}{l}\text { He/she draws a circuit plan } \\
\text { consisting of coupling in } \\
\text { series and parallel lamps }\end{array}$ & $\begin{array}{l}\text { Coupling } \\
\text { in series }\end{array}$ & $\begin{array}{l}\text { Physical } \\
\text { phenomenon }\end{array}$ \\
\hline 2 & $\begin{array}{l}\mathrm{He} / \text { she makes an inference } \\
\text { by observing the brightness } \\
\text { on the circuit in the cases } \\
\text { of coupling in series and } \\
\text { parallel }\end{array}$ & $\begin{array}{l}\text { Coupling } \\
\text { in parallel }\end{array}$ & \\
\hline 3 & $\begin{array}{l}\mathrm{He} / \text { she defines the } \\
\text { electrical circuit }\end{array}$ & $\begin{array}{l}\text { Electrical } \\
\text { current }\end{array}$ & \\
\hline 4 & $\begin{array}{l}\mathrm{He} / \text { she explains the } \\
\text { electricity energy } \\
\text { transmitted into circuits via } \\
\text { current }\end{array}$ & Voltage & \\
\hline 5 & $\begin{array}{l}\mathrm{He} / \text { she associates the } \\
\text { voltage among the points in } \\
\text { circuit components with the } \\
\text { current passing on it }\end{array}$ & & \\
\hline 6 & $\begin{array}{l}\mathrm{He} / \text { she designs an authentic } \\
\text { illumination device }\end{array}$ & & \\
\hline
\end{tabular}


analysis of data, the experimental group was found to be SD experiment $=3.36, \bar{X}$ experiment $=8.41$, and the control group was $\mathrm{SD}$ control $=8.14, \bar{X}$ control $=8.14$. The difference between average grades of academic success was very small.

t-test analysis was applied for non-paired samples to examine the difference between pre-test grades of academic success and post-test grades of academic success of the students in the control group. In Table 5, the results of t-test analysis are presented.

For the paired samples in Table 5, a significant difference was found between the grades of pre-test and post-test in control group associated to academic success levels according to t-test result $(\mathrm{t}(22)=-13.707, \rho<0.05)$. As a result of analysis of data, pre-test was seen to be SD pre-test $=2.47$, pre-test $\bar{X}=8.14$ and post-test SD post-test $=2.56, \bar{X}$ post-test $=10.77$.

t-test analysis was applied for non-paired samples to examine the difference between pre-test grades of academic success and posttest grades of academic success of the students in the experiment group. In Table 6, the results of t-test analysis are given.

For the paired samples in Table 6, a significant difference was found between the grades of pre-test and post-test in the experimental group associated to academic success

\section{Table 3: The procedures for the experimental group}

\begin{tabular}{|c|c|}
\hline Week & Procedure \\
\hline 1. & $\begin{array}{l}\text { Information was provided to the students about how to generate } \\
\text { concept maps to include arrows, directions of arrows, how and } \\
\text { where to write the explanatory information. A range of samples } \\
\text { concept maps from easy to difficult was available. Students were } \\
\text { taught how to use the free versions of "Webspiration Classroom" } \\
\text { and "LucidChart" for generating their concept maps. Students } \\
\text { were informed about the online arrangements and their ability to } \\
\text { utilize these tools both inside and outside of the classroom }\end{array}$ \\
\hline 2. & $\begin{array}{l}\text { The students were divided into four groups. In collaboration, } \\
\text { each group was to design two concept maps about the learning } \\
\text { outcomes "I. He/she draws a lamp circuit consisting of coupling } \\
\text { in series and parallel. II. He/she makes an assessment by } \\
\text { observation about the brightness of the circuit comparing the } \\
\text { series and parallel circuits. III. He/she defines the electrical } \\
\text { circuit" }\end{array}$ \\
\hline 3. & $\begin{array}{l}\text { The same groups then designed two concept maps about the } \\
\text { learning outcomes "I. He/she explains the electricity energy } \\
\text { transmitted into circuits via current. II. He/she associates the } \\
\text { voltage among the points in circuit components with the current } \\
\text { passing through it. III. He/she designs an authentic illumination } \\
\text { device." At the end of the research, the concept maps that the } \\
\text { groups designed were displayed so that they were able to be } \\
\text { evaluated }\end{array}$ \\
\hline
\end{tabular}

Table 4: Comparison of experiment and control groups according to pre-test grades (results of t-test analysis for non-paired samples)

\begin{tabular}{lccccc}
\hline Group & $\mathbf{n}$ & $\overline{\boldsymbol{X}}$ & SD & $\mathbf{t}$ & $\boldsymbol{\rho}$ \\
\hline Experiment pre-test & 22 & 8.41 & 3.36 & 0.30 & 0.767 \\
Control pre-test & 22 & 8.14 & 2.47 & 0.767 & $>0.05$ \\
\hline
\end{tabular}

$* \rho<0.05$, SD: Standard deviation levels according to $t$-test result ( $\mathrm{t}[22]=-24.029, \rho<0.05$ ). As a result of the analysis of data, pre-test was seen to be SD pre-test $=3.36, \bar{X}$ pre-test $=8.41$, and post-test SD posttest $=3.11, \bar{X}$ post-test $=13.64$.

t-test analysis was applied for non-paired samples to examine the difference in post-test grades of academic success of students taking place in the experimental and control groups. In Table 7, the results of t-test analysis are given.

For the non-paired samples in Table 7, a significant difference was found between post-test grades of academic success in the experimental group and post-test grades of academic success in the control group according to $t$-test result $(\mathrm{t}[42]=3.438$, $\rho<0.05$ ). It has been found that academic success levels of the students in the experimental group using digitally supported concept maps were more meaningful than the academic success levels of students in the control group. As a result of analysis of the data, the experimental group was seen to be SD $\bar{X}$ experiment $=3.11, \bar{X}$ experiment $=13.64$ and control group SD control $=2.56, \bar{X}$ control $=10.77$.

This study sought to determine the opinions of students toward the benefits of digitally supported concept maps in science classes. In this direction, students were asked "what are your opinions toward using digitally supported concept maps in the lessons?" The opinions toward the benefits of using digitally supported concept maps in lessons were classified in two dimensions by being subjected to content analysis which was opinions towards cognitive dimension and opinions toward affective dimension. The findings are provided in Table 8.

\begin{tabular}{|c|c|c|c|c|c|}
\hline Group & $n$ & $\bar{X}$ & SD & $t$ & $\rho$ \\
\hline Control pre-test & 22 & 8.14 & 2.47 & -13.707 & 0.000 \\
\hline Control post-test & 22 & 10.77 & 2.56 & 0.000 & $<0.05$ \\
\hline
\end{tabular}

Table 6: Comparison of pre-test and post-test results of experiment group (results of t-test analysis for paired samples)

\begin{tabular}{lccccc}
\hline Group & $\mathbf{n}$ & $\overline{\boldsymbol{X}}$ & SD & $\mathbf{t}$ & $\boldsymbol{\rho}$ \\
\hline Experiment pre-test & 22 & 8.41 & 3.36 & -24.029 & 0.000 \\
Experiment post-test & 22 & 13.64 & 3.11 & 0.000 & $<0.05$ \\
\hline *p<0.05, SD: Standard deviation & & & &
\end{tabular}

$* \rho<0.05$, SD: Standard deviation

Table 7: Comparison of experiment and control groups according to post-test grades (results of t-test analysis for non-paired samples)

\begin{tabular}{lccccc}
\hline Group & $\mathbf{n}$ & $\overline{\boldsymbol{X}}$ & SD & $\mathbf{t}$ & $\boldsymbol{\rho}$ \\
\hline Experiment post-test & 22 & 13.64 & 3.11 & 3.438 & 0.002 \\
Control post-test & 22 & 10.77 & 2.56 & 0.002 & $<0.05$
\end{tabular}

$* \rho<0.05$, SD: Standard deviation 


\begin{tabular}{|c|c|c|c|c|}
\hline \multicolumn{5}{|c|}{$\begin{array}{l}\text { Table 8: Opinions of students toward the benefits } \\
\text { of concept map methods blended with digital } \\
\text { support }(n=22)\end{array}$} \\
\hline \multirow{2}{*}{$\begin{array}{l}\text { Theme } \\
\text { Number }\end{array}$} & \multicolumn{4}{|c|}{ Benefits of method of digitally supported concept map } \\
\hline & Category & Codes & $\mathbf{F}$ & $\%$ \\
\hline 1 & \multirow{7}{*}{$\begin{array}{l}\text { Cognitive } \\
\text { dimension }\end{array}$} & Learning is easier & 8 & 26.7 \\
\hline 2 & & It embodies & 6 & 20 \\
\hline 3 & & It provides visuality & 5 & 16.7 \\
\hline 4 & & $\begin{array}{l}\text { It provides two- and } \\
\text { three-dimensional vision }\end{array}$ & 4 & 13.3 \\
\hline 5 & & It provides to learn concept & 4 & 13.3 \\
\hline 6 & & It provides to design E-concept & 3 & 10 \\
\hline Total & & & 30 & 100 \\
\hline 1 & \multirow{5}{*}{$\begin{array}{l}\text { Affective } \\
\text { dimension }\end{array}$} & It is enjoyable & 4 & 36.36 \\
\hline 2 & & It is attractive & 3 & 27.27 \\
\hline 3 & & It provides motivation & 2 & 18.18 \\
\hline 4 & & It is exciting & 2 & 18.18 \\
\hline Total & & & 11 & 100 \\
\hline
\end{tabular}

\section{DISCUSSION AND CONCLUSIONS}

In this research, a significant difference was not been found between pre-test success grades of the experimental group and pre-test success grades of the control group. It could be said that this situation was a result of the equalivance between the classes chosen as the experimental and control groups. A significant difference was found between the post-test success grades in the control group and their pre-test success grades. This difference resulted from the lesson content increasing the academic success of students from pre-test to post-test. This would be considered an expected situation. A significant difference was found between the post-test success grades of the experimental group and their pre-test. This resulted from the digitally supported concept maps implemented in the experiment group. A significant difference was found between post-test success grades of the experimental group and the post-test success grades of the control group. This result indicates that the digitally supported concept maps may have been a more efficient method than the usual lesson content practiced in control group in gaining the science outcomes to the students. The method of digitally supported concept maps used in the experimental group increased the academic successes of the students' significantly. This supports the argument that digitally supported concept maps in science classes is a method which increases the academic success of students.

This study supports research literature that has used concept map in science classes (Jegede et al., 1990; Novak et al., 1983; Pankratius, 1990; Luchembe et al., 2017) and digitally supported concept maps (Hartmeyer et al., 2017; Hwang et al., 2013; Hwang et al., 2014) which highlighted increases in the academic success of participating students.

The experimental group students' offered their opinions toward concept maps blended with digital support. According to the result, it was seen that the students made declarative statements such as "learning is easier, it embodies, it provides visuality, it provides two- and three-dimensional vision, it provides to learn concept, it provides to design E-concept" as the cognitive dimension statements; as affective dimension statements "it is enjoyable, it is attractive, it provides motivation, it is exciting" toward benefits of method of digitally supported concept maps. It is considered that these positive impressions by the students resulted from practicing the activities of concept maps in group activities and digital support. This study concurs with the literature (Chiu et al., 2000; Hwang et al., 2011; Schaal, 2010) that digitally supported concept maps constitute positive effects on students.

The academic success of students in science that implement digitally supported concept maps were higher than the students that drew concept maps manually. This situation highlights that digitally supported concept maps are a useful and effective method. The students stated that preparing the concept maps in the digital environment and developing these concept maps by sharing ideas online made the lesson more enjoyable. The students thought that the digital concept maps method was didactive, interesting, motivating, and enjoyable. Digital concept maps were a suitable method for engaging the interests and need of this digital generation.

\section{SUGGESTIONS}

\section{Suggestions for Educators}

- Using concept maps as a teaching method in teachinglearning processes increases the academic successes of students. As well, students think this method is very useful. Hence, it is suggested to use the concept maps method more frequently in teaching-learning processes.

- The preparation of concept maps through digital support increases the motivation and interest in students. It is suggested to generate concept maps in the digital environment by constituting the necessary techniques and develop concept maps blended with digital support through online applications by students.

- Students should be provided the opportunity to present their concept maps in group activities.

\section{Suggestions for Researchers}

- This research was conducted in seventh-grade science classes. It is suggested that the effects of concept maps method blended with digital support be examined in other grade levels of secondary school.

- The effects of concept maps method blended with digital support on students' motivation, attitude, and self-efficacy toward science classes in different studies should also be examined.

- The effects of concept maps method blended with digital support on students should be tested in different subject classes such as language, foreign language, and mathematics.

\section{REFERENCES}

Abebe, T.T., \& Davidson, L.M. (2012). Assessing the role of visual teaching materials in teaching english vocabulary. Language in India, 12(3), 524-552. 
Akgün, Ş. (2000). Science Teaching. Ankara: Pegem a Publishing.

Alpert, S.R., \& Grueneberg, K. (2000). Concept Mapping with Multimedia. New York: IBM Thomas J. Watson Research Division.

Aslan, Z. \& Doğdu, S. (1993). Applications of Education Technology and Education Tools. Ankara: Single Offset.

Atasoy, B. (2004). Science Learning and Teaching. Ankara: Asil Publishing Distribution.

Ausubel, D.P. (1963). The Psychology of Meaningful Verbal Learning. Oxford, England: Grune and Stratton.

Aydoğdu, Ș. (2016). The Effect of Digital Concept Maps on Students' Success and Loss in Online Learning Environments (Unpublished Doctoral Thesis). Ankara: Gazi Universtiy, Institute of Educational Sciences.

Baki, A., \& Şahin, S.M. (2004). Assessment of mathematical learning of teacher candidates via the method of computer aided concept. Turkish Online Journal of Educational Technology, 3(2), 91-104.

Bergeron, B.P., Sato, L., \& Rouse, R.L. (1994). Morphing as a means of generating variation in visual medical teaching materials. Computers in Biology and Medicine, 24(1), 11-18.

Bruillard, E., \& Baron, G.L. (2000). Computer-based concept mapping: A review of a cognitive tool for students. In: Benzie, D., \& Passey, D. (Eds.), Proceedings of Conference on Educational Uses of Information and Communication Technologies (ICEUT 2000). Beijing: Publishing House of Electronics Industry. p331-338.

Bullock, S.M. (2013). Using digital technologies to support self-directed learning for preservice teacher education. Curriculum Journal, 24(1), 103-120.

Büyüköztürk, S. (2011). Data Analysis Hand Book for Social Sciences. $14^{\text {th }}$ ed. Ankara: Pegem Publishing.

Çakmak, F. (2018). Concept maps method and usage in theology education: Concept maps belonging to unit expansions in $9^{\text {th }}$ class. Interdisciplinary Social Sciences Magazine, 2(3), 85-111.

Can, A. (2017). Quantitative Data Analysis in Scientific Research Process Via SPSS. Ankara: Pegem Publishing.

Chang, K.E., Sung, Y.T., \& Chen, S.F. (2001). Learning through computerbased concept mapping with scaffolding aid. Journal of Computer Assisted Learning, 17(1), 21-33.

Chiou, C.C. (2008). The effect of concept mapping on students' learning achievements and interests. Innovations in Education and Teaching International, 45(4), 375-387.

Chiu, C.H., Huang, C.C., \& Chang, W.T. (2000). The evaluation and influence of interaction in network supported collaborative concept mapping. Computers and Education, 34(1), 17-25.

Creswell, J.W. (2003). Research Design. California, CA: Sage Publication.

Daley, B.J., Shaw, C.A., Balistrieri, T., Glasenapp, K., \& Piacentine, L. (1999). Concept maps: A strategy to teach and evaluate critical thinking. Journal of Nursing Education, 38(1), 42-47.

Engelmann, T., \& Hesse, F.W. (2010). How digital concept maps about the collaborators' knowledge and information influence computersupported collaborative problem solving. International Journal of Computer-Supported Collaborative Learning, 5(3), 299-319.

Erden, M., \& Fidan, N. (1998). Introduction to Education. Istanbul: Alkım Publishing.

Ergin, A. (1995). Teaching Technology and Communication. Ankara: Pegem Publishing.

Fisher, K.M. (1990). Computer-based concept mapping. Journal of College Science Teaching, 19(6), 347-352.

Hartmeyer, R., Stevenson, M.P., \& Bentsen, P. (2017). A systematic review of concept mapping-based formative assessment processes in primary and secondary science education. Assessment in Education: Principles, Policy and Practice, 25(6), 598-619.

Hoyles, C., Noss, R., \& Kent, P. (2004). On the integration of digital technologies into mathematics classrooms. International Journal of Computers for Mathematical Learning, 9(3), 309.

Hsu, L.L. (2004). Developing concept maps from problem-based learning scenario discussions. Journal of Advanced Nursing, 48(5), 510-518.

Hwang, G.J., Kuo, F.R., Chen, N.S., \& Ho, H.J. (2014). Effects of an integrated concept mapping and web-based problem-solving approach on students' learning achievements, perceptions and cognitive loads. Computers and Education, 71, 77-86.
Hwang, G.J., Wu, P.H., \& Ke, H.R. (2011). An interactive concept map approach to supporting mobile learning activities for natural science courses. Computers and Education, 57(4), 2272-2280.

Hwang, G.J., Yang, L.H., \& Wang, S.Y. (2013). A concept map-embedded educational computer game for improving students' learning performance in natural science courses. Computers and Education, 69, 121-130.

Jegede, O.J., Alaiyemola, F.F., \& Okebukola, P.A. (1990). The effect of concept mapping on students' anxiety and achievement in biology. Journal of Research in Science Teaching, 27(10), 951-960.

Karamustafaoğlu, S., Karamustafaoğlu, O., \& Yaman, S. (2005). Science and Technology Education in Primary Education. Ankara: Anı Publishing.

Karasar, N. (2005). Scientific Method of Research. Ankara: Nobel Publishing Distribution.

Karpicke, J.D., \& Blunt, J.R. (2011). Retrieval Practice Produces more Learning than Elaborative Researching with Concept Mapping. Available from: http://www.science.sciencemag.org/content/331/6018/772.full. [Last accessed on 2019 Jun 10].

Kaya, O.N. (2003). An alternative way of evaluation in education: Concept Maps. Hacettepe University Journal of Education, 25(25), 265-271.

Kilıç, R. (1997). Design principles of visual teaching materials. Journal of National Education, 136, 74.

Kwon, S.Y., \& Cifuentes, L. (2009). The comparative effect of individuallyconstructed vs. collaboratively-constructed computer-based concept maps. Computers and Education, 52(2), 365-375.

Luchembe, D., Chinyama, K., \& Jumbe, J. (2017). The effect of using concept mapping on student's attitude and achievement when learning the physics topic of circular and rotational motion. European Journal of Physics Education, 5(4), 10-29.

Miles, M.B., \& Huberman, A.M. (1994). Qualitative Data Analysis: An Expanded Sourcebook. $2^{\text {nd }}$ ed. California, CA: Sage Publications.

Mutlu, B. (2009). Computer-based concept mapping. Social Studies Research and Practice, 4(3), 86-96.

Novak, J.D., \& Gowin, D.B. (1984). Learning how to Learn. Cambridge: Cambridge University Press.

Novak, J.D., Gowin, D.B., \& Johansen, G.T. (1983). The use of concept mapping and knowledge vee mapping with junior high school science students. Science Education, 67(5), 625-645.

Okursoy, F.G. (2009). The Effect of Concept Maps Teaching Strategy on Student's Success. A Meta Analysis Research (Unpublished Master's Dissertation). Istanbul, Turkey: Marmara University, Institute of Educational Sciences.

Ören, F.Ş., \& Ateş, Ö. (2018). Evaluation of Micro Teaching Applications Using Analogy via Concept Maps. Ankara: Pegem Publishing.

Özyürek, L. (1998). Teaching Principles and Methods. Ankara: Ankara University Educational Sciences Publishing.

Palaiologou, I. (2016). Children under five and digital technologies: İmplications for early years pedagogy. European Early Childhood Education Research Journal, 24(1), 5-24.

Pankratius, W.J. (1990). Building an organized knowledge base: Concept mapping and achievement in secondary school physics. Journal of Research in Science Teaching, 27(4), 315-333.

Prensky, M. (2004). The Emerging Online Life of the Digital Native Available from: http://www.marcprensky.com/writing/Prensky-The Emerging_Online_Life_of_the_Digital_Native-03.pdf. [Last accessed on 2019 Jun 10].

Roberts, P., \& Priest, H. (2006). Reliability and validity in research. Nursing Standard, 20, 41-45.

Şahin, F. (2001). Designing and applying concept map of teacher candidates. Pamukkale University Education Faculty Magazine, 10(10), 12-25.

Şahin, F. (2002). A research about using concept maps as assessment tool. Pamukkale University Education Faculty Magazine, 11(11), 17-32.

Şahin, Y.T., \& Yıldırım, S. (1999). Developing Teaching Technology and Material. Ankara: Anı Publishing.

Schaal, S. (2010). Cognitive and motivational effects of digital concept maps in pre-service science teacher training. Procedia-Social and Behavioral Sciences, 2(2), 640-647.

Tergan S.O. (2005) Digital concept maps for managing knowledge and information. In: Tergan, S.O., \& Keller, T. (Eds.), Knowledge and Information Visualization. Lecture Notes in Computer Science. Berlin: 
Springer. p185-204.

Tergan, S.O., Keller, T., \& Burkhard, R.A. (2006). Integrating knowledge and information: Digital concept maps as a bridging technology. Information Visualization, 5(3), 167-174.

Topkaya, E. Z. (2013). Qualitative Research Methods in Social Sciences. Theory and Practice in Education, 2(2), 113-118.

Turgut, M.F., Baker, D., Cunningham, R., \& Piburn, M. (1997). Council of Higher Education/World Bank Project of Improving National Education Pre-service Teacher Education. Ankara: MEB Publishing.

Tzeng, J.Y. (2009). The impact of general and specific performance and self- efficacy on learning with computer-based concept mapping. Computers in Human Behavior, 25(4), 989-996.

Yaşar, O., \& Şeremet, M. (2010). An evaluation of teaching methods and materials used in geography teaching in Turkish higher education regarding a number of variables. Journal of Human Sciences, $7(1), 675-702$.

Yllmaz, K., \& Colak, R. (2012). The effect of using concept maps in teaching social sciences on the attitude, academic success and information permanence of students. Cumhuriyet International Journal of Education, 1(1), 1-16. 